\title{
THE BIOINDICATION EVALUATION OF GROUND BEETLES (COLEOPTERA: CARABIDAE) IN THREE FOREST BIOTOPES IN THE SOUTHERN PART OF CENTRAL SLOVAKIA
}

\author{
VLADIMÍR LANGRAF ${ }^{1}$, KORNÉLIA PETROVIČOVÁ², STANISLAV DAVID ${ }^{1}$, JANKA \\ NOZDROVICKÁ ${ }^{1}$, FRANTIŠEK PETROVIČ ${ }^{1}$, JANKA SCHLARMANNOVÁ ${ }^{3}$
}

${ }^{1}$ Department of Ecology and Environmental Sciences, Faculty of Natural Sciences, Constantine the Philosopher University in Nitra, Tr. A. Hlinku 1, Nitra, Slovak Republic; e-mail: langrafvladimir@gmail.com, sdavid@ukf.sk, jana.nozdrovicka@ukf.sk, fpetrovic@ukf.sk

${ }^{2}$ Department of Environment and Zoology, Faculty of Agrobiology and Food Resources Slovak University of Agriculture in Nitra, Tr. A. Hlinku 2, 94976 Nitra, Slovak Republic; e-mail: kornelia.petrovicova@gmail.com ${ }^{3}$ Department of Zoology and Anthropology, Faculty of Natural Sciences, Constantine the Philosopher University in Nitra, Tr. A. Hlinku 1, Nitra, Slovak Republic; e-mail: jschlarmannova@ukf.sk

\begin{abstract}
Langraf V., Petrovičová K., David S., Nozdrovická J., Petrovič F., Schlarmannová J.: The bioindication evaluation of ground beetles (Coleoptera: Carabidae) in three forest biotopes in the southern part of Central Slovakia. Ekológia (Bratislava), Vol. 38, No. 1, p. 25-36, 2019.

Ground beetles (Carabidae) were used to evaluate the bio indication environmental incidence. The ground beetle material (2,341 individuals, 30 species) was collected between 2015 and 2017 using pitfall traps in three types of forest habitats with different disturbance rates. The comparison of carabid's sensitivity as bio indicators has been evaluated by using three methods: (i) community index of ground beetles (IKS), (ii) ellipsoid biovolume (EV) and (iii) flight ability of the carabids. Using the Monte Carlo permutation test, we did not record the statistically significant changes in IKS values, nor does a change in the representation of carabids in the bioindicative group A, $\mathrm{E}$ and R. On the contrary, we confirmed the statistically significant changes in the average values of ellipsoid biovolume in biotopes and between biotopes (the Friedman and Kruskal-Wallis test ANOVA ( $p$-value $=0.00)$ ). A higher number of macropterous species were recorded in biotopes with high disturbance as compared to the biotopes with low disturbance.
\end{abstract}

Key words: carabids, bio indicators, community index of the ground beetles, ellipsoid biovolume, flight ability, Slovakia.

\section{Introduction}

Approximately $80 \%$ of the human population of industrialized countries live in towns. It is important to know what the impact of human activity is on cultural aspects, and to identify factors that influence species biodiversity for biodiversity conservation in town surroundings. It is also important to find out and test the indicators of the biodiversity status, as well 
as its causes and changes (Pickett et al., 2001). The most commonly used bioindicators from invertebrate fauna are the orders of Araneae (Buchar, 1983), Diplopoda, Chilopoda (Tuf, Tufová, 2008), Odonata (David, 2001) and Coleoptera (Boháč, 2007). The Coleoptera order - especially the Carabidae family - is rich in species. These are species with well-known autecology, inhabiting various habitat types. They react sensitively to the presence of different toxic substances, and to $\mathrm{pH}$ and soil moisture change (Cárcamo, Spence, 1994; Stork, 1990).

In forest ecosystems, the carabids react to the changes derived from the character of the tree layer. The structure of their communities change due to tree cutting intensity but also with forest restoration (Šteffek et al., 2008). The clear-cut of trees changes the microclimate of habitat and its light conditions, and thus reflects the species composition and phenology of herbal communities (Heithecker, Halpern, 2006). Forest clear-cutting have caused a decline in some specialized forest species of the Carabidae. Eurytopic species that are typically found in open areas, ruderal habitats and fields (Elek et al., 2001; Finch, 2005; Wiezik et al., 2007) have replaced these species. This species exchange is typical in locations such as oak forests and beech-fir forests, at up to approximately $900 \mathrm{~m}$ a. s. 1 . At higher altitudes, there is a reduction in species exchange because there is a reduction in the occurrence of the areas cultivated; and the field (segetal) species (Šustek, 2005). Šteffek et al. (2008) proposes that these changes are a reflection of the ecological degradation of ecosystems and are associated with human activities in the environment. Stluka (2013) confirmed the carabid response to tree cutting in spruce forests using the Community Index of the Ground Beetles (IKS). He considers that the intensity of management increases the number of euryvalent species in the forest ecosystem. Rajová (2007) also recorded a higher proportion of adaptable species compared to the eurytopic species found in the intact Klánovický Forest (the Czech Republic). The results of Langraf et al. (2016) also confirm that the anthropogenic influence on the forest deteriorates the living conditions of the adaptable and relict species. These conclusions also apply to the undisturbed mountain meadow biotopes in the Veporské vrchy hills. There was a predominance of eurytopic species (bioindication group E) in the intensively influenced forest and meadow biotopes of the Juhoslovenská kotlina basin. Another indicator, which determines the environmental pollution level, is the change in body size (ellipsoid biovolume) and vagility (distributing the species in a certain area) (McGeogh, 1998). Szyszko (1983) formulated and confirmed the hypothesis 'the decrease of environmental disturbance allows for a larger than average body size', while he was studying ground beetles during the restoration of a pine forest. Šustek (1987) pointed out the decreasing body size of the Carabidae in areas that are under intensive anthropogenic disturbance. The body size of a Carabidae is associated with flight ability, which is related to the appearance of apterous and brachypterous species. (Majzlan, Frantzová, 1994). The reverse is also true - macropterous species have a smaller than average body size in biotopes. Porhajášová, Šustek (2011) confirmed that the species that live in stable ecosystems, have lost their flight ability. Flight ability endures within those species that come from ecosystems exposed to cyclical changes. Rainoi, Niemalä (2003) recorded a trend for the Carabidae, which shows that the number of apterous species decreases with the increasing disturbance, and on the contrary, the number of macropterous species increases. Similarly, Shibuya et al. (2014) also discovered that macropterous beetle species dominated in grass ecosystems and apterous and brachypterous species dominated in forest ecosystems. 
These results show that the predominance of apterous and brachypterous species indicates significant environmental stability, and macropterous species indicates a less stable environmental ecosystem.

The aim of our paper is to evaluate the changes in the values of the Index of community of the ground beetles (IKS), body size (ellipsoid biovolume), and flight ability of the Carabidae in the three biotope types between 2015 and 2017. We focused on evaluating the three hypotheses: 1) the Index of community of the ground beetles (IKS) values decrease with the increasing intensity of biotopes' disturbance; 2 ) the average body size value (EV) of ground beetles decreases with the increasing intensity of biotopes disturbance; and 3) the number of macropterous species increases with the increasing intensity of biotopes disturbance.

\section{Material and methods}

Ground beetle research took place from 2015 to 2017 in the three localities that represent the three types of biotopes with varying intensities of anthropogenic influence: The Culture of Picea abies, Carpathian oak-hornbeam forest and Carpathian turkey oak forest. In 2015, the traps were set from 17th April to 23rd October; in 2016 from 7th May to 30th October; and in 2017, from 15th April to 30th October. The material was collected seven times in each year at regular three-week intervals. We used the pitfall traps $(720 \mathrm{ml})$ (Novák et al., 1969), five pitfall traps were set in one line per each biotope in 10 metres distances. As a fixation fluid, we used $4 \%$ saline. We identified the ground beetles according to Hurka (1996), the nomenclature and flight ability of the species from Carabidae (apterous (A), brachpterous (B) and macropterous (M)) follow Hůrka (1996).

\section{Study area}

The study areas are located in the southern part of Central Slovakia near the town of Lučenec and Poltár and the village of Utekáč (Table 1).

$\mathrm{T}$ a b l e 1. Location data of the study localities.

\begin{tabular}{|l|l|l|l|l|l|l|}
\hline Geomorphological unit & \multicolumn{2}{|l|}{ study site } & C. a. & m a. s.l. & Biotope & G. C. \\
\hline Veporské vrchy hills & 1 & Lichovo & Utekáč & 518 & Culture of Picea abies & $\begin{array}{l}48^{\circ} 36^{\prime} 27^{\prime \prime} \mathrm{N} \\
19^{\circ} 48^{\prime} 23^{\prime \prime} \mathrm{E}\end{array}$ \\
\hline \multirow{2}{*}{ Juhoslovenská kotlina basin } & 2 & Kúpna hora & Poltár & 300 & $\begin{array}{l}\text { Carpathian } \\
\text { oak-hornbeam forest }\end{array}$ & $\begin{array}{l}48^{\circ} 26^{\prime} 02^{\prime \prime} \mathrm{N} \\
19^{\circ} 49^{\prime} 31^{\prime \prime} \mathrm{E}\end{array}$ \\
\cline { 2 - 7 } & 3 & near Ladovo & Lučenec & 258 & $\begin{array}{l}\text { Carpathian turkey oak } \\
\text { forest }\end{array}$ & $\begin{array}{l}48^{\circ} 19^{\prime} 49^{\prime \prime} \mathrm{N} \\
19^{\circ} 37^{\prime} 06^{\prime \prime} \mathrm{E}\end{array}$ \\
\hline
\end{tabular}

Notes: C. a. - Cadastral area; m a.s.l. - metres above sea level; G.C. - geographic coordinates.

The study plot 1 (Lichovo) is characterised by black berries (Rubus fruticosus agg.) in the undergrowth of approximately 20 years forest cover of old Norway spruce (Picea abies). During 2016, a small number of trees, which the great spruce bark beetles (Ips typographus) has attached themselves to and infested them, were finally cut. They were at a distance of 3 to $5 \mathrm{~m}$ away from the trap lines. In study plot 2 (Kúpna hora), the 50-60 years old oak-hornbeam forest was formed by the species of hornbeams (Carpinus betulus), black locusts (Robinia pseudoacacia), pedunculate oaks (Quercus robur), and sessile oaks (Q. petraea). Thin shrub undergrowth consist of privet (Ligustrum vulgare), spindle tree (Euonymus europaeus) and especially younger hornbeams (Carpinus betulus), black locusts (Robinia pseudoacacia), pedunculate oaks (Quercus robur), in the height up to $3 \mathrm{~m}$. The ground zone consists of leaf litter without vegetation. In 2016, forest tree cutting took place $60 \mathrm{~m}$ from the trap lines. Study site 3 (near Ladovo) is the Carpathian turkey oak forest, which is $80-100$ years old. This tree zone is represented by species of field maple 
(Acer campestre), hornbeam (Carpinus betulus), Turkey oak (Quercus cerris) and pedunculate oak (Q. robur). Field maple and hornbeam (Acer campestre and Carpinus betulus) dominate in the shrub zone. Coralroot (Dentaria bulbifera), fumeworts (Corydalis spp.) and cleavers (Galium aparine) dominate in the herb zone. Intensive forest tree cutting took place $40 \mathrm{~m}$ from the trap lines during the years 2016 and 2017.

The following methods were used for the bioindication evaluation of ground beetles at the localities: the community index of the ground beetles (IKS) (Nenadál, 1998), ellipsoid biovolume (EV) (volume - body size) (Brauna et al., 2004) and the flight ability of the Carabidae (Hůrka, 1996) and (Majzlan, Frantzová, 1994).

\section{Computation of the Carabidae Ellipsoid biovolume (EV)}

The morphometric signs were measured for each individual using a digital microscope ( $0.1 \mathrm{~mm}$ accuracy): (i) the length - dorsal length between the upper lip (labium) and the terminal part of elytra, (ii) the width - dorsal length between the maximum width of the elytra, and (iii) the height - the maximum dorsoventrally thickness of the left side of the body. Each parameter was measured three times to minimize error, and the final value is their arithmetic average. According to Braun et al. (2004), the ellipsoid biovolume (EV) from our measured morphometric signs (length, width, height) used the formula:

$$
\mathrm{EV}=(\pi / 6) \times \mathrm{L} \times \mathrm{H} \times \mathrm{W}
$$

where: $\mathrm{L}=$ individual length, $\mathrm{H}$ = individual height, $\mathrm{W}=$ individual width.

Computation community index of the ground beetles (IKS)

Ground beetles we divided into three bioindication classes according to Farkač et al. (2006):

- Group R - relicts, stenotopic species, narrow ecological valence - mostly rare and endangered species of natural ecosystems.

- Group A - adaptable species which colonize semi-natural habitats, they occur in secondary, good regenerating biotopes and its ecotones.

- $\quad$ Group E - eurytopic species without special requirements on the character and quality of environment. They occur in unstable and changing biotopes with strong anthropogenic influence.

The Index of Community of ground beetles (IKS) is calculated according to Nenadál (1998) based on the division of the Carabidae into bioindication groups (A, E, R). We use the following formula:

$\mathrm{IKS}=100-\left(\sum \mathrm{E}+0.5 \times \Sigma \mathrm{A}\right)$

where $\mathrm{E}=$ percentage of individuals in group $\mathrm{E}(\mathrm{E} \%), \mathrm{A}=$ percentage of individuals in group $\mathrm{A}(\%)$.

The IKS index includes the values ranging from zero to 100 . In cases where the index value is close to zero, we identified mostly species of group E. Conversely, when the value of index is close to 100; there are mostly species from group R. The final values included five classes according to the Nenadal's (1998) classification scale of human influence on habitat: I (0-15) strongly influenced, II (10-35) significantly influenced, III (30-50) influenced, IV (45-65) marginally influenced and V (65-100) not influenced.

\section{Data analyses}

For the analysis of morphometric parameters, Ellipsoid biovolume (EV), flight ability and community index of the ground beetles (IKS), were used statistic methods (StatSoft, 2004; Ter Brak, Šmilauer, 2004). Distribution normality (the Shapiro-Wilk's W test), homogeneity of variance (the Levene's test), compliance of average values (the Friedman test - ANOVA), (the Kruskal-Wallis test - ANOVA) correlation of years to EV values and correlation of biotope types to IKS values and bioindication groups (A, E, R) (the Monte Carlo permutation test) were analysed by the methods of inductive statistics. We used data matrix of all species with the number of individuals at the sites and matrix of species of bioindication groups A, E, R and IKS values.

Thanks to the level of significance $\mathrm{p}_{\alpha}=0.05$ (if $\mathrm{p}>\mathrm{pa}$, we cannot reject $\mathrm{H}_{0}$ according to the level of significance $\mathrm{p}_{\alpha}=0.05$ ). $\mathrm{H}_{0}$ hypotheses was tested - (i) Random selection comes from a set of normal values distribution; (ii) Random selection comes from a set of normal values dispersion; (iii) In the years 2015 and 2017, there is no difference in the average value of EV in all localities; (iv) Linear regression model is statistically significant. 


\section{Results and discussion}

During the research, we found 2,341 individuals (1,111 males, 1,230 females) belonging to 30 species (Table 2). According to the values of index of community of ground beetles (IKS), the largest species representation from all found specimens belonged to group A - adaptable (21 species; 2,294; individuals $=70 \%$ ). A smaller percentage of species belonged to group $\mathrm{E}$ - eurytopic ( 7 species; 34 individuals $=23.33 \%)$. Group $\mathrm{R}$ - relicts was represented by two species and 13 individuals $=6.67 \%$. Rajová (2007) recorded a higher representation of group A species in intact stands of the Klánovický Forest (the Czech Republic) compared to the localities located on the edge of the forest in contact with the meadow and stream where the species from group E prevailed.

According to the classification scale of anthropogenic influence on habitat, the biotopes belong to class III (influenced) or IV (lower influenced). IKS values over the three years between the beetle assemblages in localities did not differ significantly. The following summarises the IKS values we recorded in the forest: pine stand of Picea abies (IKS = 49), Carpathian oak-hornbeam forest $($ IKS $=48)$ and Carpathian turkey oak forest $($ IKS $=46)$. The IKS values in study sites 1 and 2 decreased during 2016, due to the cutting of invaded trees there. In 2017, there was a small increase (Table 2) of IKS values. On the contrary, the highest decrease in IKS values were found in 2017 at the study site Carpathian turkey oak forest, which was due to the continuing cutting of trees. Using the IKS (Stluka, 2013) also confirmed that tree cutting has strong anthropic impact. We found a significant decrease in IKS values in the tree cutting forest and the lowest in the spruce forest. Langraf et al. (2016) noted the predominance of group $\mathrm{E}$ (eurytopic) species in a habitat in the tree cutting forest. We assume that after removing most of the trees in biotope Carpathian turkey oak forest, the carabids from group E would replace the species of group A. The lower IKS value in this study site was influenced by the presence of a higher number of individuals Calathus fuscipes and Pseudoophonus rufipes belonging to group E. These species are typical in arable lands, which surround this locality. There was also tree cutting there and newly created open area offered to carabids to penetrate there.

The difference in the representation of the Carabidae bioindication groups of A, E, R and IKS values among the study sites over the years 2015 and 2017 was evaluated by a redundancy analysis (RDA, the highest value of lengths of gradient $=1.38)$ (Fig. 1). RDA analysis explained the variability of species data in the first ordination axis $(76.1 \%)$ and in the second ordination axis (90\%). Variability of species data explained by the environmental variables in the first ordination axis was $71.6 \%$; and in the second axis, it was $85 \%$. The maximum value of inflation factor was 1,551. We confirmed the species of group A correlated with carabids from the study biotopes pine stand Picea abies and Carpathian turkey oak forest, where they were represented mostly. We expected the binding of group A species, although intensive tree cutting prevails carabids form the study biotope Carpathian turkey oak forest and the flying of macroporous species belonging to group E also occurs. The complete exchange of groups would only occur after the forest was cut. The vectors, which show the individual years (2015-2017) for this group, did not deviate significantly, indicating only small changes in the number of species for group A. The species of group R correlated with carabids from 
T a b l e 2. Distribution of the Carabids based on bioindication groups of flight ability in the study sites.

\begin{tabular}{|c|c|c|c|c|c|}
\hline \multirow[b]{2}{*}{ species } & \multirow[b]{2}{*}{ KBS } & \multirow[b]{2}{*}{ F.A. } & \multicolumn{3}{|c|}{ Study site } \\
\hline & & & 1 & 2 & 3 \\
\hline Abax ovalis (Duftschmid, 1812) & A & $\mathrm{B}$ & 12 & - & - \\
\hline Abax parallelepipedus (Piller \& Mitterpacher, 1783) & A & B & 145 & 54 & 115 \\
\hline Abax parallelus (Duftschmid, 1812) & A & $\mathrm{B}$ & 51 & 19 & 26 \\
\hline Amara familiaris (Duftschmid, 1812) & $\mathrm{E}$ & M & - & 1 & - \\
\hline Amara saphyrea Dejean, 1828 & $\mathrm{~A}$ & M & - & - & 3 \\
\hline Aptinus bombarda (Illiger, 1800) & $\mathrm{R}$ & $\mathrm{B}$ & - & 2 & 9 \\
\hline Calathus fuscipes (Goeze, 1777) & $\mathrm{E}$ & M & - & - & 4 \\
\hline Calosoma inquisitor (Linnaeus, 1758) & A & A & - & - & 2 \\
\hline Carabus cancellatus Illiger, 1798 & A & A & 6 & - & - \\
\hline Carabus convexus (Fabricius, 1775) & A & A & 5 & - & 1 \\
\hline Carabus coriaceus Linnaeus, 1758 & A & A & 19 & 75 & 60 \\
\hline Carabus glabratus Paykull, 1790 & A & A & 237 & - & 2 \\
\hline Carabus granulatus Linnaeus, 1758 & $\mathrm{E}$ & B & - & - & 4 \\
\hline Carabus hortensis Linnaeus, 1758 & A & A & 332 & 368 & 212 \\
\hline Carabus intricatus Linnaeus, 1761 & A & A & 15 & 20 & 3 \\
\hline Carabus nemoralis O.F.Müller, 1764 & A & $\mathrm{A}$ & 45 & 5 & 43 \\
\hline Carabus violaceus Linnaeus, 1758 & A & A & 168 & 27 & 22 \\
\hline Cychrus caraboides (Linnaeus, 1758) & A & A & 12 & - & - \\
\hline Cymindis humeralis (Fourcroy, 1785) & A & $\mathrm{B}$ & 2 & 4 & 1 \\
\hline Harpalus rubripes (Duftschmid, 1812) & $\mathrm{E}$ & $\mathrm{M}$ & - & - & 1 \\
\hline Leistus rufomarginatus (Duftschmid, 1812) & $\mathrm{R}$ & M & - & 2 & - \\
\hline Molops elatus (Fabricius, 1801) & $\mathrm{A}$ & $\mathrm{B}$ & - & - & 2 \\
\hline Molops piceus (Panzer, 1793) & A & $\mathrm{B}$ & 87 & 2 & 21 \\
\hline Nebria brevicollis Fabricius, 1792 & A & M & - & - & 4 \\
\hline Notiophilu biguttatus (Fabricius, 1799) & A & $\mathrm{B}$ & - & 2 & - \\
\hline Ophonus azureus (Fabricius, 1777) & $\mathrm{E}$ & $\mathrm{B}$ & 3 & - & - \\
\hline Pseudoophonus rufipes (De Geer, 1774) & $\mathrm{E}$ & $\mathrm{M}$ & - & 3 & 17 \\
\hline Pterostichus melanarius (Illiger, 1798) & $\mathrm{E}$ & $\mathrm{B}$ & - & 1 & - \\
\hline Pterostichus niger (Schaller, 1783) & $\mathrm{A}$ & $\mathrm{M}$ & 20 & - & 1 \\
\hline Pterostichus oblongopunctatus (Fabricius, 1787) & A & M & 1 & 14 & 29 \\
\hline$\sum$ species & - & - & 17 & 16 & 22 \\
\hline$\sum$ species KBS-A/flight ability A & 21 & 10 & $16 / 9$ & $11 / 5$ & $17 / 7$ \\
\hline$\sum$ species KBS-E/flight ability B & 7 & 11 & $1 / 6$ & $3 / 6$ & $4 / 6$ \\
\hline$\Sigma$ species KBS-R/flight ability $M$ & 2 & 9 & $0 / 2$ & $2 / 5$ & $1 / 9$ \\
\hline IKS value in 2015 & - & - & 50 & 50 & 50 \\
\hline IKS value in 2016 & - & - & 49,1 & 47,2 & 46,3 \\
\hline IKS value in 2017 & - & - & 49,2 & 47,8 & 43,1 \\
\hline Total IKS value for the years 2015-2017 & - & - & 49 & 48 & 46 \\
\hline
\end{tabular}

Notes: KBS- categories of bioindication groups A, E and R; F.A.- flight ability of the Carabids: apterous (A), brachypterous (B), macropterous (M); 1- locality 1 (Culture of Picea abies), 2 - locality 2 (Carpathian oak-hornbeam forest), 3 - locality 3 (Carpathian turkey oak forest). 
localities two and three; the vectors did not change over the years 2016 and 2017. For the year 2015, the vector is not representative due to the absence of the group R species. Biotopes Carpathian oak-hornbeam forest and Carpathian turkey oak forest were mostly represented by species from group E, as shown by the correlation of this group among 2015-2017. The vectors markedly deviated between 2015 and 2016, indicating a change in the number of species from group E. The vectors for IKS values have deviated significantly between 2015 and 2016. Between 2016 and 2017, there was also a separation of the vectors, which was not as significant as the year before. The above-mentioned fact, the deviation of vectors for IKS values and the number of species from group E points to the tree cutting of wood in biotope Carpathian turkey oak forest, which had begun in 2016 and continued until 2017. In 2015, group R did not occur in study localities; therefore, it is not in the chart and Monte Carlo permutation test. The maximum value of inflation factor was $=4.73$. Using the Monte Carlo permutation test, we did not confirm statistical significance of IKS values and bioindication

Fig. 1. RDA analysis of species representation of groups A, E, R and IKS values from 2015 to 2017 .

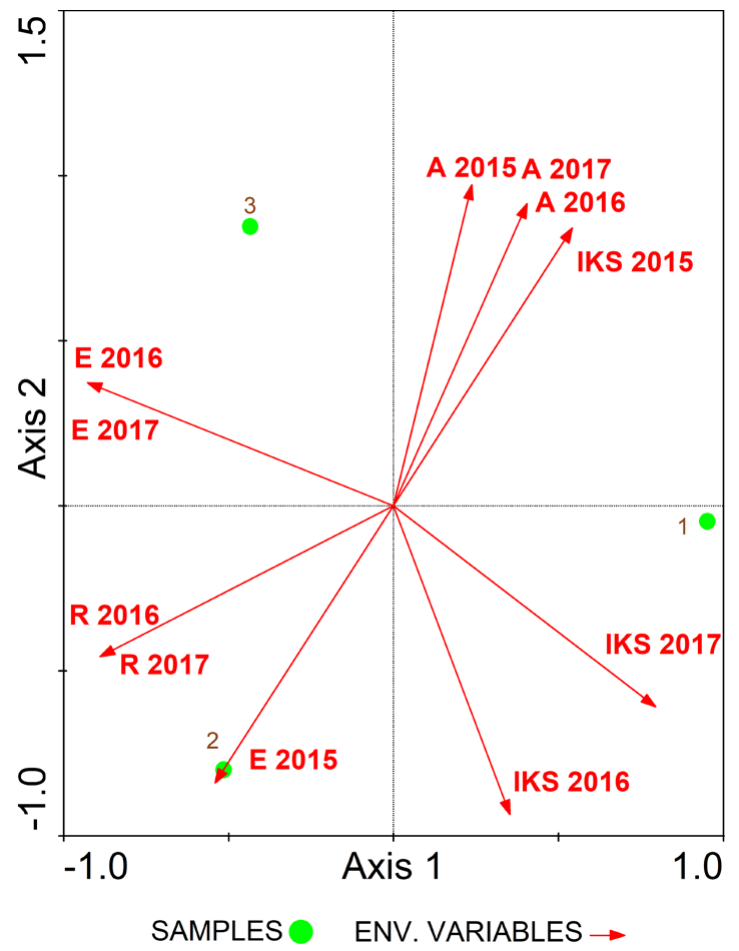

Notes: 1, 2, 3 - locality number. R 2015-2017 species of indicator group R for 2015 to 2017, E 2015-2017 species of indicator group E for the years 2015 to 2017, A 2015-2017 species of indicator group A for 2015 to 2017 , IKS 2015-2017 values of community index of ground beetles for the years 2015 to 2017. groups (A, E, R) for 2015 to 2017.

The Carabidae were divided into three bioindication groups according to their flight ability: apterous (A), brachypterous (B), macropterous (M). The largest species spectrum belonged to the group B (11 species $36.67 \%$; 562 individuals), a smaller presence of the species was in the group A ( 10 species $=33.33 \%$; 1679 individuals); in the group $M$, were 9 species $=33 \%$ (100 individuals) (Table 2). The slight prevalence of brachypterous species above theapterous species were recorded in all the study sites as was also found by Farkač et al. (2006) too. The predominance of macropterous species was recorded in the biotope Carpathian turkey oak forest due to the intensive tree cutting of wood and prevalence of species that prefer arable land and meadows: Calathus fuscipes, Harpalus rubripes, Nebria brevicollis and Pseudoophonus rufipes. In our study of carabids in three different sites, there has been a decline in the apterous species that indicates greater stability of the environment. Subsequently, they have 
been replaced by the macropterous species indicating a less stable environment. In the biotope Carpathian oak-hornbeam forest, there was tree cutting of wood during a particular year (2016); therefore, the number of macropterous species was lower than in the biotope Carpathian turkey oak forest. Shibuya et al. (2014) find that apterous and brachypterous species dominated over macropterous species in forest ecosystems. He confirmed that when the forest vegetation is disturbed, there is an increase in the number of macropterous species. During the study of spatial structure (Porhajášová, Šustek, 2011) of carabids in wetland area, the authors found that macropterous species live in ecosystems exposed to cyclical changes and the predominance of apterous species indicates significant environmental stability. Rainoi, Niemalä (2003) pointed to the reduction in the number of apterous species due to the increasing disturbance. On the contrary, the number of macropterous species has increased due to disturbance.

The ellipsoid biovolume (EV) value was determined based on our measured morphometric analyses (length, thickness and width of body) of all the individuals. The total EV value of carabids represented $1,756,503 \mathrm{~mm}^{3}(1.7 \mathrm{l})$ per 2,431 individuals and 30 species. EV values for the period under review were following: study site $1=773269 \mathrm{~mm}^{3}(0.77 \mathrm{l})$, study site 2 $=549332 \mathrm{~mm}^{3}(0.54 \mathrm{l})$ and study site $3=433901 \mathrm{~mm}^{3}(0.43 \mathrm{l})$.

A non-parametric Friedman test for testing $\mathrm{H}_{0}$ hypothesis was used because of distribution normality data disruption (the Shapiro-Wilk's W test [p-value $=0.00]$ ) and homogeneity of variance disruption (the Levene's test $[p$-value $=0.00]$ ). The result of testing the average compliance of $\mathrm{EV}$ values is $\mathrm{H}_{0}$ rejection $(p$-value $=0.00$ ) during 2015 and 2017 in each locality. This means that the EV average values are statistically different (Fig. 2) for all the years in each locality. The statistically significant difference in individual localities in EV values for 2015-2017 confirmed the Kruskal-Wallis test. Results are following: biotope pine stand of Picea abies ( $\mathrm{p}$-value $=0.00$ ), biotope Carpathian oak-hornbeam forest ( $\mathrm{p}$-value $=0.00$ ), biotope Carpathian turkey oak forest ( $\mathrm{p}$-value $=0.00$ ). The decrease in the EV average value was recorded in the study site 3 , which was affected by intensive tree cutting of wood. In biotopes of pine stand of Picea abies and Carpathian oak-hornbeam forest, the EV value decreased in 2016, but had a subsequent increase in 2017. Szyszko (1983) also formulated and confirmed the hypothesis that the decrease of environmental disturbance allows for a bigger average $\mathrm{EV}$ value, while he was studying ground beetles during the restoration of a pine forest. Šustek (1987) confirmed the same fact. The predominance of apterous and brachypterous species, which have a larger average size than macropterous species, was recorded in all three forest biotopes confirmed Majzlan, Frantzová (1994) as well.

The correlation coefficient was high $r=0.99$, indicating a very strong relationship of the measured EV values to the years of collection. The confidence coefficient $r^{2}=0.99$, explains the capture of $99 \%$ of the EV variability during the years 2015-2017. The overall suitability of the regression model is statistically significant $(p$-value $=0.03)$ and so the result confirms the effect of the species spectrum in years trapping on the EV values. We can predict (Fig. 3) the EV value for 2018 , which would be $28,020 \mathrm{~mm}^{3}$. EV values for the period under review were: $2015=903299 \mathrm{~mm}^{3}, 2016=563433 \mathrm{~mm}^{3}$ and $2017=289770 \mathrm{~mm}^{3}$. Significant decline in EV values during the period under review - 2015-2017 and the predicted year 2018 - is due to the tree cutting of wood in biotopes Carpathian oak-hornbeam forest and Carpathian turkey oak forest. 


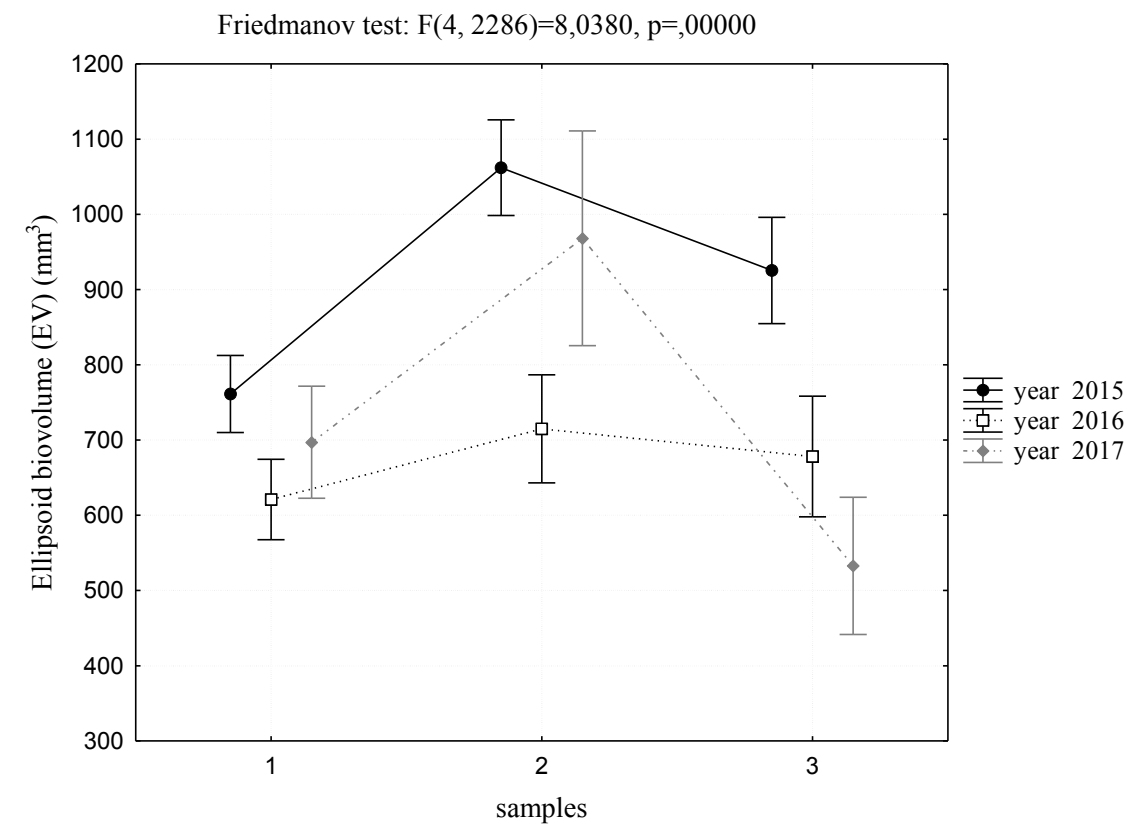

Fig. 2. Analysis of variance (Friedman test (ANOVA)) of the Carabidae species average EV values during 2015-2017 in each study site with $95 \%$ confidence.

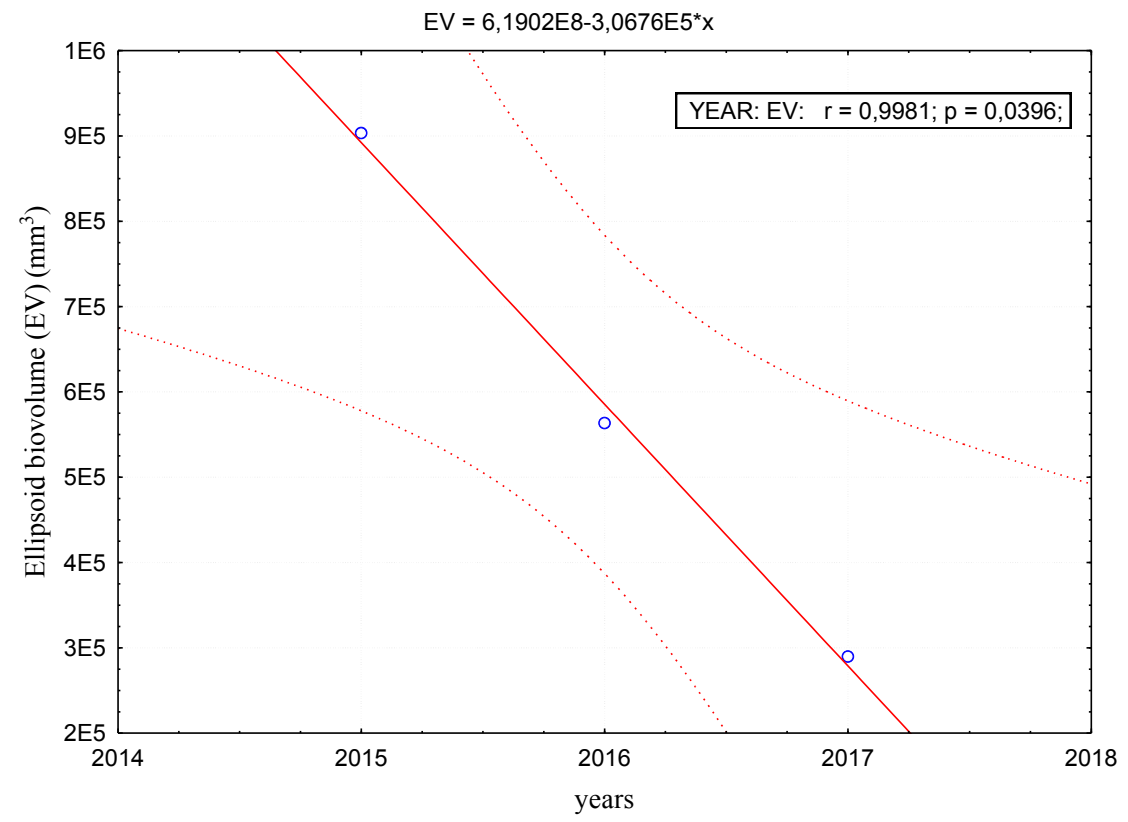

Fig. 3. The linear regression model of EV values for years 2015-2017, with $95 \%$ confidence. 
In study sites, there is likely to be a decline in the apterous species, which have their food optimum in biotopes and indicate greater stability of the environment. Subsequently, they will be replaced by macropterous species, which will seek food because of their lack of it. All these indicate a less stable environment. Šteffek et al. (2008), Elek et al. (2001), Finch (2005) and Wiezik et al. (2007) pointed to a change in the structure of the Carabidae community due to tree cutting of wood or its renewal. Šustek (2005) remarked that such a species exchange is typical for the locations from oak forests to beech-fir forests, approximately up to $900 \mathrm{~m} \mathrm{a}$. s. 1. Our research took place in the range from 258 to $518 \mathrm{~m}$ a. s. 1 .

\section{Conclusion}

The different intensity of anthropogenic influences (tree cutting of wood) on the Carabidae species were evaluated in three study sites in Slovakia (three types of forest habitats).

Using the Community Index of Ground Beetles (IKS), we did not confirm the statistically significant changes in values over the years 2015-2017. No statistically significant changes in the number of bio-indicating species (A, E, R categories) were confirmed, while the total representation of the species included in the bioindication groups was significant (A - 21 species; E - 7 species; R - 2 species). Statistically significant decrease in IKS values in the direction from the less disturbed biotope (study site 1) to a more disturbed biotope (study site 3 ) were not confirmed. Consequently, we did not confirm our first hypothesis.

The highest human activity were found in the Carpathian turkey oak forest. Based on the evaluation of the Carabidae flight ability, a higher number of macropterous species, we can declare the high impact of intensive tree cutting. This is associated with the occurrence of species that prefer the open landscape (field and meadow species): Calathus fuscipes, Harpalus rubripes, Nebria brevicollis and Pseudoophonus rufipes. There were 10 apterous species, 11 brachypterous and 9 macropterous species.

The decrease in EV values during the years 2015-2017 and predicted year 2018 is caused by tree cutting. In the study of carabids at the three study sites, there is a decline in apterous species, which indicate greater stability of the environment. Subsequently, they were replaced by the macropterous species, which indicate a less stable environment. The statistically significant decrease in the average EV values in the direction from the less disturbed biotope to a more disturbed biotope was confirmed. A higher number of macropterous species was recorded in the biotope Carpathian turkey oak forest 3, which was affected by intensive tree cutting that confirmed our third hypothesis.

The valuation of ecological stability is considered on the basis of the present status evaluation, such as future alternatives of land use. Ground beetles are a very important model bioindicative organisms that reflect environmental changes and they may be used for landscape planning documents in Slovakia (e.g., development of environmental systems). Bioindication evaluation using $\mathrm{EV}$ and flight ability of carabid beetles can be used as one of the assessment approaches to the environmental quality and the intensity of human activity impact on the landscape.

\section{Acknowledgements}

This research is supports by the project VEGA 1/0496/16: Assessment of natural capital, biodiversity and ecosystem services in Slovakia - basis for practical implementation of integrated environmental policy. 


\section{References}

Boháč, J. (2007). Kapitola z připravované knihy „Půdní biologie“. Pudní zoologie - dravý hmyz, Brouci (Coleoptera): Střevlíkovití (Carabidae) a drabčíkovití (Staphylinidae). http://docplayer.cz/16165184-Kapitola-z-pripravovaneknihy-pudni-biologiepudni-zoologie-dravy-hmyz-brouci-coleoptera-strevlikoviti-carabidae-a-drabcikovitistaphylinidae.html

Braun, S.D., Jones, T.H. \& Perner J. (2004). Shifting average body size during regeneration after pollution - a case study using ground beetle assemblages. Ecol. Entomol., 29, 543-554. DOI: 10.1111/j.0307-6946.2004.00643.x.

Buchar, J. (1983). Klasifikace druhů pavoučí zviŕreny Čech jako pomůcka k bioindikaci kvality životního prostředí. Fauna Bohemiae Septentrionalis, 8, 119-135.

Cárcamo, H.A. \& Spence J.R. (1994): Crop type effects on the activity and distibution of ground beetles (Coleoptera, Carabidae). Environ. Entomol., 23(3), 123-140. DOI: 10.1093/ee/23.3.684.

David, S. (2001). Bioindikační využití vážek (Insecta: Odonata) na př́íkladě potamalu řeky Ipel' (JZ Slovensko). Acta Facultatis Rerum Naturalium Universitatis Ostraviensis, Biológia - Ekológia, 8, 93-99.

Elek, Z., Magura, T. \& Tóthmérész B. (2001). Impacts of non-native Norway spruce plantation on abundance and species richness of ground beetles (Coleoptera: Carabidae). Web Ecology, 2, 32-37. DOI: 10.5194/we-2-32-2001.

Farkač, J., Kopecký, T. \& Veselý P. (2006). Využitie střevlíkovitých (Coleoptera, Carabidae) fauny Slovenska k indikaci kvality prostředí. Ochrana Přírody, 25, 226-242.

Finch, O.D. (2005). Evaluation of mature conifer plantations as secondary habitat for epigeic forest arthropods (Coleoptera: Carabidae; Aranae). For. Ecol. Manag., 204, 23-36. DOI: 10.1016/j.foreco.2004.07.071.

Heithecker, T.D. \& Halpern C.B. (2006). Variation in microclimate associated with dispersed-retention harvests in coniferous forests of western Washington. For. Ecol. Manag., 226, 60-71. DOI: 10.1016/j.foreco.2006.01.024.

Hůrka, K. (1996). Carabidae of the Czech and Slovak Republics. Zlín: Kabourek.

Langraf, V., Petrovičová, K., David, S. \& Schlarmannová J. (2016). The bioindication importance of the Carabidae communities of Veporské vrchy and Juhoslovanská kotlina. Ekológia (Bratislava), 35, 126-135. DOI: 10.1515/ eko-2016-0010.

Majzlan, O. \& Frantzová E. (1994). Štruktúra a dynamika bystruškovitých (Coleoptera, Carabidae) epigeonu v intraviláne mesta Nitry. Rosalia, 10, 107-118.

McGeogh, M.A. (1998). The selection, testing and application of terrestrial insects as bioindicators. Biol. Rev., 73, 181-201. DOI: 10.1111/j.1469-185X.1997.tb00029.x.

Nenadál, S. (1998). Využití indexu komunity střevlíkovitých (Coleoptera,Carabidae) pro posouzení antropogenních vlivů na kvalitu př́rodního prostředí. Vlastivědný Sborník Vysočiny, 13, 293-312.

Novák, K., Balát, F., Bartoš, E., Bouček, Z., Daniel, M., Dlabola, J., Doskočil, J., Holman, J., Jagemann, E., Kunst, M., Landa, V., Lang, J., Mařan, J., Miller, F., Nosek, J., Novák, K., Obenberger, J., Obr, S., Pelikán, J., Raušer, J., Rosický, B., Rusek, J., Schwarz, J., Skuhravý, V., Slouková, M., Šilhavý, V., Štys, P., Teyrovský, V., Vondráček, K., Zahradník, J. \& Zelenský J. (1969). Metódy sběru a preparace hmyzu. Praha: Academia.

Pickett, S.T.A., Cadenasso, M.L., Grove, J.M., Nilon, C.H., Pouyat, R.V., Zipperer, W.C. \& Costanza R. (2001). Urban ecological systems: linking terrestrial ecological, physical, and socioeconomic components of metropolitan areas. Annu. Rev. Ecol. Syst., 32, 127-157. www.jstor.org/stable/2678637

Porhajašová, J. \& Šustek Z. (2011). Priestorová štruktúra spoločenstiev bezstavovcov s dôrazom na čelad' Carabidae v prírodnej rezervácii Žitavský Luh. Nitra: SPU.

Rainio, J. \& Niemalä J. (2003). Ground beetles (Coleoptera: Carabidae) as bioindicators. Biodivers. Conserv., 12, 487-506. DOI: 10.1023/A:1022412617568.

Rajová, Š. (2007). Využití hmyzu k výuce biologie. Střevlíkovití (Coleoptera: Carabidae) Klánovického lesa a posouzení stavu jeho zachovalosti metodou bioindikace. Dissertation thesis, Karlova Univerzita, Katedra biologie a ekologické výchovy, Praha.

Shibuya, S., Kikvidze, Z., Toki, W., Kamazawa, Y., Suizu, T., Yajima, T., Fujimori, T., Mansournia, M.R., Sule, Z., Kubota, K. \& Fukuda K. (2014). Ground beetle community in suburban Satoyama - A case study on wing type and body size under small scale management. Journal of Asia-Pacific Entomology, 17, 775-780. DOI: 10.1016/j. aspen.2014.07.013.

Statsoft, Inc. (2004) Statistica 7. Softwarový systém na analýzu dat. www.StatSoft.Cz

Stluka, P. (2013). Vliv managementu na biodiverzitu lesních ekosystémů- epigeičtí brouci na vybraných biotopech Písecka. Diploma thesis, Jihočeská Univerzita v Českých Budějovicích, Zemědělská fakulta.

Stork, N. (1990) The role of ground beetles in ecological and environmental studies. Andover: Intercept. 
Szyszko, J. (1983). State of Carabidae (Col.) fauna in fresh pine forest and tentative valorisation of this environment. Warsaw: Agricultural University Press.

Šteffek, J., Gallay, I., Gallayová, Z., Kunca, V., Lepeška, T., Olah, B., Škvareninová, J., Ujházyová, M., Wiezik, M. \& Križanová Z. (2008). Krajinnoekologický výskum. Zvolen: FEE, Technická Univerzita vo Zvolene.

Šustek, Z. (1987). Changes in body size structure of carabid community (Coleoptera, Carabidae) along an urbanisation gradient. Biológia (Bratislava), 42, 145-156.

Šustek, Z. (2005). Ground beetles (Coleoptera, Carabidae) and their response to changes of vegetation in alpine ecosystems. Folia Faunistica Slovaca, 10(5), 19-22.

Ter Brak, C.J.F. \& Šmilauer P. (2002). CANOCO reference manual and user's guide to Canoco for Windows. Wageningen: Centre for Biometry.

Tuf, H.I. \& Tufová J. (2008). Proposal of ecological classification of centipede, millipede and terrestrial isopod faunas for evaluation of habitat quality in Czech Republic. Časopis Slezského Zemského Muzea, 57(1), 37-44.

Wiezik, M., Svitok, M. \& Dovčiak M. (2007). Conifer introductions decrease richness and alter composition of litter-dewlling beetles (Coleoptera) in Carpathian oak forests. For. Ecol. Manag., 247, 61-71. DOI: 10.1016/j. foreco.2007.04.013. 